Галаган В. I., канд. військ. наук, доцент (ORCID: 0000-0001-9578-0895);

Полішко С. В. канд. техн. наук, ст. наук. співроб. (ORCID: 0000-0002-2172-7618);

Бондарчук C. B. (ORCID: 0000-0003-0624-9782)

Центр воєнно-стратегічних досліджень Національного університету оборони України імені Івана Черняховського, Київ

\title{
Пропозиції щодо удосконалення процесу впровадження інформаційних систем іноземного виробництва в діяльність Збройних Сил України
}

Резюме. У статті проведено порівняльний аналіз підходів до розроблення та впровадження інформаційних систем іноземного виробництва з вимогами нормативних документів України та на його основі розроблені рекомендації щодо розв'язання проблемних питань єдиного розуміння етапів (фаз, процесів) розроблення та впровадження інформаційних систем іноземного виробництва в діяльність військових організацій (структур) Збройних Сил України.

Ключові слова: впровадження інформаційних систем; етапи розроблення та впровадження; удосконалення процесу впровадження.

Постановка проблеми. Збройні Сили України на сьогодні знаходяться на етапі проведення оборонної реформи. Відповідно до положень Стратегічного оборонного бюлетеня України [1] очікуваним результатом $\epsilon$ створення за принципами та стандартами, прийнятими в державах-членах НАТО, ефективних, мобільних, оснащених сучасним озброєнням, військовою і спеціальною технікою сил оборони зразка 2020 року, здатних гарантовано забезпечити оборону держави та адекватно і гнучко реагувати на воєнні загрози національній безпеці України, раціонально використовувати до того ж наявний потенціал (спроможності) та ресурси держави.

Відповідно до поставлених завдань, одним із найактуальніших завдань під час оборонної реформи $є$ також створення та впровадження інформаційних систем управління.

На сьогодні в Збройних Силах України (в рамках Плану дій щодо впровадження оборонної реформи у Міністерстві оборони та Збройних Силах України у 2016 - 2020 роках та Концепції інформатизації Міністерства оборони України) створюються i впроваджуються інформаційні системи управління оборонними ресурсами (Defense Resources Management Information System DRMIS).

До того ж за роки незалежності в Збройних Силах України не було створено жодної завершеної інформаційної системи як управління військами (силами), так i оборонними ресурсами.

Проблема розроблення та впровадження інформаційних систем управління оборонними ресурсами, окрім фінансових та політичних аспектів, полягає у відсутності єдиного розуміння та використанні різних підходів до їх розроблення та впровадження. А проте, майже не використовується світовий досвід та не має чіткого порядку розподілу етапів розроблення та впровадження інформаційних систем іноземного виробництва відповідно до вимог нормативних документів України. Це, як правило, призводить до великих часових затримок з реалізації проєктів або їх зупинки.

Ступінь розробленості проблеми. На сьогодні в більшості фахових публікацій [2-4] 3 розроблення та впровадження інформаційних систем не має чіткого поняття щодо проблем які виникають під час цього процесу. В основі цих робіт проводиться визначення основних завдань і можливі напрями розвитку. Водночас, проведений аналіз $є$ декларативнішим та не вказує шляхи розв'язання проблеми щодо створення та впровадження інформаційних систем. Тим більше, що зовсім не розглядаються проблеми, які виникають під час прийняття у постійну (промислову) експлуатацію іноземних програмних продуктів щодо їх відповідності нормативним документам України.

Такий стан викликає необхідність розроблення та надання відповідних пропозицій щодо можливих шляхів розв'язання проблемних питань єдиного розуміння процесів розроблення та впровадження інформаційних систем іноземного виробництва в діяльність військових організацій (структур) Збройних Сил України ЗС України.

3 огляду на викладене, метою статті $\epsilon$ проведення порівняльного аналізу підходів до 
розроблення та впровадження інформаційних систем іноземного виробництва 3 вимогами нормативних документів України та на його основі розроблення рекомендацій щодо формування єдиного розуміння етапів (фаз, процесів) розроблення та впровадження інформаційних систем іноземного виробництва в діяльність військових організацій (структур) Збройних Сил України.

Виклад основного матеріалу. Нині без сучасної інформаційної системи управління оборонними ресурсами не можливо уявити ефективних і мобільних Збройних Сил. Проте більшість розвинених країн, які мають передові збройні сили особливу увагу приділяють впровадженню рішень, в яких інтегруючою та базовою ланкою $\epsilon$ ERPсистема (Enterprise Resource Planning System система планування ресурсів структури) [5].

В умовах динамічного розвитку збройних сил життєвий цикл інформаційних систем значно скорочується, а вимоги до функціональних можливостей значно зростають. Отже 3 кожним роком удосконалюються концепції та програмні продукти. Одним зі світових лідерів у розробленні комплексних бізнес-рішень, який вже давно зайшов на ринок України та використовується в Збройних Силах України є компанія $S A P A G$ (Німеччина). Тим більше, що цей програмний продукт успішно використовується не тільки в бізнесструктурах, але й збройних силах (США, Великобританія, Німеччина, Канада, Норвегія, Польща).

Важливим чинником для Збройних Сил України, які знаходяться в умовах розвитку 3 обмеженим бюджетним фінансуванням $\epsilon$ позитивні сторони SAP. До них можна віднести основні принципи будівництва та роботи системи - спеціалізацію та інтеграцію.
Використання цих принципів означає, що кожний компонент або продукт, який належить до продуктів або послуг $S A P$, відповідає певним потребам, таким як забезпечення доступу до других $S A P$-систем на базі вебтехнологій, адресація вимог планування життєвого циклу продукту, підтримка внутрішньої служби забезпечення, об'єднання різних систем для спрощення проблем, пов'язаних з інтеграцією [6].

Має певні особливості і сам процес впровадження $S A P$, який є досить масштабним і вартісним, та може зайняти від шести місяців до декількох років.

Сама методологія SAP складається 3 п’яти фаз:

підготовка проєкту;

концептуальне проєктування;

реалізація проєкту;

завершальна підготовка проєкту;

продуктивна експлуатація i підтримка проєкту.

Підготовка проєкту. На цій фазі проєкт набуває статусу фактичного початку. Фаза включає в себе такі задачі:

аналіз і уточнення стратегії реалізації; визначення організаційної структури проєкту;

аналіз і уточнення стратегії навчання; проведення навчання проєктної групи; визначення стандартів i процедур управління проєктом;

визначення стратегії побудови

системного ландшафту;

проведення наради по фактичному початку (запуску) проєкту.

Під час виконання задач фази підготовки проєкту відпрацьовується низка документів. Перелік основних вихідних документів фази підготовки проєкту наведено в табл. 1.

Таблиця 1

Перелік основних вихідних документів фази підготовки проскту

\begin{tabular}{|l|l|l|l|}
\hline \multicolumn{1}{|c|}{ Назва } & \multicolumn{1}{|c|}{ Відповідальний } & \multicolumn{1}{c|}{ Узгоджує } & \multicolumn{1}{c|}{ Затверджує } \\
\hline Устав проєкту & $\begin{array}{l}\text { Оперативні } \\
\text { керівники }\end{array}$ & $\begin{array}{l}\text { Рада управління, } \\
\text { Стратегічні керівники }\end{array}$ & Керівник проєкту \\
\hline План проєкту & $\begin{array}{l}\text { Оперативні } \\
\text { керівники }\end{array}$ & $\begin{array}{l}\text { Рада управління, } \\
\text { Стратегічні керівники }\end{array}$ & Керівник проєкту \\
\hline План навчання & $\begin{array}{l}\text { Оперативні } \\
\text { керівники }\end{array}$ & $\begin{array}{l}\text { Рада управління, } \\
\text { Стратегічні керівники }\end{array}$ & Керівник проєкту \\
\hline
\end{tabular}

Концептуальне проєктування. На цій фазі визначається деталізований порядок діяльності структурних підрозділів (установ) Збройних Сил України. Також визначаються параметри бізнес-процесів, формується уявлення про цілі, функціональні напрями i організаційну структуру Збройних Сил
України. Також визначається метод реалізації цих процесів за допомогою функціональності SAP. Результатом виконання цієї фази $є$ документ, окремий для кожного функціонального напряму - концептуальний проєкт. 
Фаза концептуального проєктування включає в себе такі задачі:

встановлення середовища розробки;

початкове встановлення системного

ландшафту;

адміністрування системи;

ініціація $I M G$ (керівництво 3

впровадження системи);

проведення нарад щодо бізнес-процесів;

проведення нарад із визначення

детальних вимог до системи;

проведення навчання проєктної групи;

нарада із закриття фази і переходу до наступної фази.
Для забезпечення початку цієї фази найважливішим фактором $є$ виконання перелічених нижче умов:

затвердження складу робочих груп;

наявність робочого середовища для робочих груп.

Під час виконання задач фази концептуального проєктування відпрацьовується низка документів. Перелік основних вихідних документів концептуального проєктування наведено в табл. 2.

Перелік основних вихідних документів фази концептуального проєктування

\begin{tabular}{|l|l|l|l|}
\hline \multicolumn{1}{|c|}{ Назва } & \multicolumn{1}{|c|}{ Відповідальний } & \multicolumn{1}{|c|}{ Узгожує } & \multicolumn{1}{|c|}{ Затверджує } \\
\hline $\begin{array}{l}\text { Концептуальний проєкт за } \\
\text { функціональними } \\
\text { напрямами }\end{array}$ & $\begin{array}{l}\text { Начальники } \\
\text { функціональних } \\
\text { робочих груп, } \\
\text { Оперативні керівники }\end{array}$ & $\begin{array}{l}\text { Рада управління, } \\
\text { Стратегічні } \\
\text { керівники }\end{array}$ & $\begin{array}{l}\text { Заступник } \\
\text { Керівника проєкту }\end{array}$ \\
\hline Технічний проєкт & Оперативні керівники & $\begin{array}{l}\text { Заступник } \\
\text { Керівника проєкту }\end{array}$ & Керівник проєкту \\
\hline
\end{tabular}

Реалізація. На цій фазі виконується конфігурування системи з урахуванням вимог, які поставлені замовником (Збройними Силами України) i визначені в концептуальному проєкті. Під час фази надається основна можливість передачі знань від консультантів членам робочих груп.

Основною передумовою початку фази реалізації є повністю готовий концептуальний проєкт. Також до передумов належать такі вимоги:

готовність технічного проєкту по серверам;

наявність всього необхідного

обладнання;

налаштований системний ландшафт 3 наявною транспортною телекомунікаційною мережею, яка передбачає існування трьох окремих систем (система розробки, система тестування i контролю якості, продуктивна система).

Фаза включає в себе такі задачі: прототипу; розроблення програм переносу даних; розроблення розширень системи; розроблення інтерфейсних програм; створення звітно-друкованих форм; створення або уточнення концепції повноважень користувачів; створення робочих місць кінцевих користувачів; розроблення сценарію інтеграційного тестування конфігурування системи, інтеграційне тестування; початкове планування підтримки продуктивної експлуатації; системне адміністрування;

створення план-графіків навчання кінцевих користувачів, створення документації кінцевих користувачів;

нарада із закриття фази i переходу до наступної.

Під часі виконання задач фази реалізації відпрацьовується низка документів. Перелік основних вихідних документів фази реалізації наведено в табл. 3.

Таблиця 3

Перелік основних вихідних документів фази реалізації

\begin{tabular}{|l|l|l|l|}
\hline \multicolumn{1}{|c|}{ Назва } & \multicolumn{1}{|c|}{ Відповідальний } & \multicolumn{1}{|c|}{ Узгоджує } & \multicolumn{1}{|c|}{ Затверджує } \\
\hline $\begin{array}{l}\text { Протоколи інтеграційного } \\
\text { тестування (результати) }\end{array}$ & $\begin{array}{l}\text { Начальники } \\
\text { функціональних } \\
\text { робочих груп }\end{array}$ & Оперативні керівники & $\begin{array}{l}\text { Заступник } \\
\text { Керівника проєкту }\end{array}$ \\
\hline
\end{tabular}

Для забезпечення початку цієї фази найважливішим фактором $є$ виконання таких умов: затвердження концептуального проєкту; затвердження основного переліку бізнеспроцесів. 
Завершальна підготовка. На цій фазі здійснюється підготовка до продуктивного використання системи.

Фаза включає в себе такі задачі:

уточнення планів підготовки системи до продуктивного старту;

підготовка i занесення основних довідників;

підготовка і занесення початкових

даних;

виконання перевірки якості;

навчання кінцевих користувачів;

завершальне

налаштування

продуктивності системи;

завершальне тестування за участю

кінцевих користувачів (дослідна

експлуатація);

нарада із закриття фази і переходу до наступної.
Завершальне тестування включає в себе такі роботи: підготовка набору даних для завершального тестування; проведення завершального тестування.

Для забезпечення початку фази найважливішим фактором $\epsilon$ такі умови:

позитивні результати інтеграційного тесту;

готовність інструментарію занесення основних даних;

затвердження наказу про початок продуктивної експлуатації;

готовність інструментарію із занесення початкових даних і початкових залишків.

завершення навчання кінцевих

користувачів.

Під час виконання задач фази реалізації відпрацьовується низка документів. Перелік основних вихідних документів фази заключної підготовки наведено в табл. 4.

Таблиця 4

Перелік основних вихідних документів фази реалізації

\begin{tabular}{|c|c|c|c|}
\hline Назва & Відповідальний & Узгоджус & Затверджус \\
\hline $\begin{array}{lr}\text { Рішення про } & \text { готовність } \\
\text { системи до завершального } \\
\text { тестування } & \text { (дослідної } \\
\text { експлуатації) } & \\
\end{array}$ & Оперативна рада & Рада управління & $\begin{array}{l}\text { Заступник } \\
\text { Керівника проєкту }\end{array}$ \\
\hline $\begin{array}{l}\text { Протокол } \quad \text { навчання } \\
\text { кінцевих користувачів }\end{array}$ & $\begin{array}{l}\text { Начальники } \\
\text { функціональних } \\
\text { робочих груп } \\
\end{array}$ & Рада управління & $\begin{array}{l}\text { Заступник } \\
\text { Керівника проєкту }\end{array}$ \\
\hline $\begin{array}{lr}\text { Протокол } & \text { завершального } \\
\text { тестування } & \text { (дослідної } \\
\text { експлуатації) } & \end{array}$ & $\begin{array}{l}\text { Начальники } \\
\text { функціональних } \\
\text { робочих груп }\end{array}$ & $\begin{array}{l}\text { Оперативні керівники, } \\
\text { Рада управління }\end{array}$ & $\begin{array}{l}\text { Заступник } \\
\text { Керівника проєкту }\end{array}$ \\
\hline $\begin{array}{l}\text { Рішення про готовність } \\
\text { системи до приймальних } \\
\text { випробувань }\end{array}$ & $\begin{array}{l}\text { Рада управління, } \\
\text { оперативні керівники }\end{array}$ & $\begin{array}{l}\text { Заступник } \text { Керівника } \\
\text { проєкту }\end{array}$ & $\begin{array}{l}\text { Рада директорів, } \\
\text { Керівник проєкту }\end{array}$ \\
\hline
\end{tabular}

\section{Продуктивна експлуатація $i$} підтримка. На фазі продуктивної експлуатації забезпечується задоволення потреб кінцевих користувачів на момент початку роботи із системою.

Передумовами цієї фази є:

готовий проєкт по мережам;

наявність робочих місць, обладнаних персональними комп'ютерами, підключеними до продуктивної системи;

створення необхідних компонентів комплексної системи захисту інформації; відповідність існуючої інфраструктурної зони, вибраній пілотній зоні продуктивної експлуатації.

Фаза включає в себе такі задачі:

створення групи підтримки

продуктивної експлуатації;

підтримка продуктивної експлуатації;

визначення довгострокових планів;

наступне навчання i розвиток групи підтримки; закриття проєкту;

нарада, присвячена фактичному закінченню проєкту.

Водночас, нормативні документи (державний стандарт) України у сфері автоматизованих систем вимагають обов'язкового виконання певного переліку заходів під часі їх розроблення та впровадження [7].

Відповідно до вимог ГОСТ 34.601-90: "Процес створення автоматизованої системи (АС) $€$ сукупністю впорядкованих в часі, взаємозв'язаних, об'єднаних в стадії і етапи робіт, виконання яких необхідне і достатне для створення АC, що відповідає заданим вимогам".

3 огляду на раціональне планування i організацію робіт, що закінчуються заданим результатом, стадії та етапи створення АС $\epsilon$ частинами процесу їі створення.

Склад та правила виконання робіт на встановлених стандартом стадіях і етапах 
визначають у відповідній документації організацій, що беруть участь у створенні конкретної АC.
Стадії та етапи створення $\mathrm{AC}$ у загальному випадку наведені в табл. 5.

Стадії та етапи робіт відповідно до ГОСТ 34.601-90

Таблиця 5

\begin{tabular}{|c|c|}
\hline Стадії & Етапи робіт \\
\hline \multirow[t]{3}{*}{ 1. Формування вимог до АС } & 1.1. Обстеження об’єкта і обгрунтування необхідності створення АС \\
\hline & 1.2. Формування вимог користувача до АC \\
\hline & $\begin{array}{l}\text { 1.3. Оформлення звіту про виконану роботу і заявки на розроблення } \\
\text { AC }\end{array}$ \\
\hline \multirow[t]{4}{*}{ 2. Розроблення концепції АС } & 2.1. Вивчення об’єкта \\
\hline & 2.2. Проведення необхідних науково-дослідних робіт \\
\hline & $\begin{array}{l}\text { 2.3. Розроблення варіантів концепції АС і вибір варіанта концепції АC, } \\
\text { задовольняючого вимогам користувача }\end{array}$ \\
\hline & 2.4. Оформлення звіту про виконану роботу \\
\hline 3. Технічне завдання & 3.1. Розроблення і затвердження технічного завдання на створення АC \\
\hline \multirow[t]{2}{*}{ 4. Ескізний проєкт } & $\begin{array}{l}\text { 4.1. Розроблення попередніх проєктних рішень по системі та іiі } \\
\text { частинах }\end{array}$ \\
\hline & 4.2. Розроблення документації на АС та ії частини \\
\hline \multirow[t]{4}{*}{ 5. Технічний проєкт } & 5.1. Розроблення проєктних рішень по системі та їі частинах \\
\hline & 5.2. Розроблення документації на АС та її частини \\
\hline & $\begin{array}{l}\text { 5.3. Розроблення і оформлення документації на постачання виробів для } \\
\text { комплектування АС і (або) технічних вимог (технічних завдань) на їх } \\
\text { розроблення }\end{array}$ \\
\hline & $\begin{array}{l}\text { 5.4. Розроблення завдань на проєктування в } \\
\text { проєкту об'єкта автоматизації }\end{array}$ \\
\hline \multirow{2}{*}{ 6. Робоча документація } & 6.1. Розроблення робочої документації на систему та їі частини \\
\hline & 6.2. Розроблення або адаптація програм \\
\hline \multirow[t]{8}{*}{ 7. Впровадження } & 7.1. Підготовка об’єкта автоматизації до введення АС в дію \\
\hline & 7.2. Підготовка персоналу \\
\hline & $\begin{array}{l}\text { 7.3. Комплектація АС виробами, що поставляються (програмними i } \\
\text { технічними засобами, програмно-технічними } \\
\text { iнформаційними виробами) }\end{array}$ \\
\hline & 7.4. Будівельно-монтажні роботи \\
\hline & 7.5. Пусконалагоджувальні роботи \\
\hline & 7.6. Проведення попередніх випробувань \\
\hline & 7.7. Проведення дослідної експлуатації \\
\hline & 7.8. Проведення приймальних випробувань \\
\hline \multirow[t]{2}{*}{ 8. Супроводження АC } & 8.1. Виконання робіт відповідно до гарантійних зобов'язань \\
\hline & 8.2. Післягарантійне обслуговування \\
\hline
\end{tabular}

Стадії i етапи, що виконуються організаціями-учасниками робіт зі створення $\mathrm{AC}$, встановлюються в договорах і технічному завданні на підставі цього стандарту.

Допускається виключати стадію "Ескізний проєкт" і окремі етапи робіт на всіх стадіях, об'єднувати стадії “Технічний проєкт" i "Робоча документація" в одну стадію “Техноробочий проєкт". Залежно від специфіки створюваних $\mathrm{AC}$ i умов їх створення допускається виконувати окремі етапи робіт до завершення попередніх стадій, паралельне в часі виконання етапів робіт, включення нових етапів робіт.
Отже, проаналізувавши вимоги кожного 3 процесів, для виконання робіт згідно 3 вимогами ГОСТ 34.601-90 і відповідно до методології впровадження SAP необхідно встановити відповідність між стадіями i етапами робіт, визначеними ГОСТ і фазами методології SAP.

Використовуючи порівняльний аналіз встановлюємо відповідність між стадіями і етапами робіт по ГОСТ та фазами робіт методології впровадження SAP - результати якої наведено в табл. 6 . 
Відповідність етапів робіт по ГОСТ фазам робіт методології впровадження SAP

\begin{tabular}{|c|c|c|}
\hline Стадії по ГОСТ & Етапи робіт & Фази методології $S A P$ \\
\hline \multirow[t]{3}{*}{$\begin{array}{l}\text { 1. Формування вимог } \\
\text { до АС } \\
\end{array}$} & $\begin{array}{l}\text { 1.1. Обстеження об’єкта і обгрунтування } \\
\text { необхідності створення АС }\end{array}$ & Підготовка Проєкту \\
\hline & 1.2. Формування вимог користувача до АC & Підготовка Проєкту \\
\hline & $\begin{array}{l}\text { 1.3. Оформлення звіту про виконану роботу } \\
\text { i заявки на розроблення АС }\end{array}$ & Підготовка Проєкту \\
\hline \multirow{4}{*}{$\begin{array}{l}\text { 2. Розроблення } \\
\text { Концепції АС }\end{array}$} & 2.1. Вивчення об’єкта & Підготовка Проєкту \\
\hline & $\begin{array}{l}2.2 . \quad \text { Проведення необхідних } \\
\text { дослідних робіт }\end{array}$ & Підготовка Проєкту \\
\hline & $\begin{array}{l}\text { 2.3. Розроблення варіантів Концепції } \mathrm{AC} \mathrm{\textrm {i }} \\
\text { вибір варіанта Концепції АC, що } \\
\text { задовольняє вимогам користувача }\end{array}$ & Підготовка Проєкту \\
\hline & 2.4. Оформлення звіту про виконану роботу & Підготовка Проєкту \\
\hline 3. Технічне завдання & $\begin{array}{l}\text { 3.1. Розроблення і затвердження технічного } \\
\text { завдання на створення АС }\end{array}$ & Підготовка Проєкту \\
\hline \multirow[t]{2}{*}{ 4. Ескізний проєкт } & $\begin{array}{lrl}\text { 4.1. Розроблення попередніх } & \text { проєктних } \\
\text { piшень по системі та ії частинах } & \\
\end{array}$ & $\begin{array}{l}\text { Концептуальне } \\
\text { проєктування }\end{array}$ \\
\hline & $\begin{array}{l}\text { 4.2. Розроблення документації на АC та іï } \\
\text { частини }\end{array}$ & $\begin{array}{l}\text { Концептуальне } \\
\text { проєктування }\end{array}$ \\
\hline \multirow[t]{4}{*}{ 5. Технічний проскт } & $\begin{array}{l}\text { 5.1. Розроблення проєктних рішень на АС та } \\
\text { iї частини }\end{array}$ & $\begin{array}{l}\text { Концептуальне } \\
\text { проєктування }\end{array}$ \\
\hline & $\begin{array}{l}\text { 5.2. Розроблення документації на АC та іï } \\
\text { частини }\end{array}$ & $\begin{array}{l}\text { Концептуальне } \\
\text { проєктування }\end{array}$ \\
\hline & $\begin{array}{l}\text { 5.3. Розробка і оформлення документації на } \\
\text { постачання виробів для комплектування АС } \\
\text { i (або) технічних вимог (технічних завдань) } \\
\text { на їх розробку }\end{array}$ & $\begin{array}{l}\text { Концептуальне } \\
\text { проєктування }\end{array}$ \\
\hline & $\begin{array}{l}\text { 5.4. Розроблення завдань на проєктування в } \\
\text { суміжних частинах проєкту об’єкта } \\
\begin{array}{l}\text { автоматизації } \\
\end{array}\end{array}$ & $\begin{array}{l}\text { Концептуальне } \\
\text { проєктування }\end{array}$ \\
\hline \multirow[t]{2}{*}{ 6. Робоча документація } & $\begin{array}{l}\text { 6.1. Розроблення робочої документації на } \\
\text { АС та iї частини }\end{array}$ & Реалізація \\
\hline & 6.2. Розроблення або адаптація програм & Реалізація \\
\hline \multirow[t]{8}{*}{ 7. Введення в дію } & $\begin{array}{l}\text { 7.1. Підготовка об’єкта автоматизації до } \\
\text { введення АС в дію }\end{array}$ & Завершальна підготовка \\
\hline & 7.2. Підготовка персоналу & Завершальна підготовка \\
\hline & $\begin{array}{l}\text { 7.3. Комплектування АС виробами, що } \\
\text { постачаються (програмними i технічними } \\
\text { засобами, програмно-технічними } \\
\text { комплексами, інформаційними виробами) }\end{array}$ & $\begin{array}{l}\text { Реалізація, } \\
\text { підготовка }\end{array}$ \\
\hline & 7.4. Будівельно-монтажні роботи & Реалізація \\
\hline & 7.5. Пусконалагоджувальні роботи & $\begin{array}{l}\text { Реалізація, } \\
\text { підготовка }\end{array}$ \\
\hline & 7.6. Проведення попередніх випробувань & Реалізація \\
\hline & 7.7. Проведення дослідної експлуатації & Завершальна підготовка \\
\hline & 7.8. Проведення приймальних випробувань & Завершальна підготовка \\
\hline \multirow[t]{2}{*}{ 8. Супроводження АС } & $\begin{array}{l}\text { 8.1. Виконання робіт відповідно до } \\
\text { гарантійних зобов'язань }\end{array}$ & $\begin{array}{l}\text { Продуктивна } \\
\text { та підтримка }\end{array}$ \\
\hline & 8.2. Післягарантійне обслуговування & $\begin{array}{l}\text { Продуктивна } \\
\text { та підтримка }\end{array}$ \\
\hline
\end{tabular}

Тобто, використовуючи порівняльний аналіз є можливість провести співставлення завдань i заходів кожного із етапів (фаз, процесів), що надалі дасть змогу успішно розробляти і впроваджувати нові програмні продукти не виходячи за межі вимог керівних документів України.

Висновки. Таким чином, проведений аналіз показує, що в кожному окремому випадку використання іноземних програмних продуктів в діяльності структур (установ) 


\section{ІНФОРМАТИЗАЦІЯ ТА УПРАВЛІННЯ ПРОЄКТАМИ ІНФОРМАТИЗАЦЇ̈ ЗБРОЙНИХ СИЛ}

Збройних Сил України потребує обов'язкового використання індивідуального підходу до розгляду та порівняння етапів (фаз, процесів) розроблення та впровадження, що дасть змогу надалі роз'вязати проблемні питання їх відповідності вимогам нормативних документів України.

Подальші дослідження за цією тематикою доцільно зосередити на питаннях удосконалення нормативно-правової бази України щодо впровадження нових інформаційних продуктів.

\section{СПИСОК ВИКОРИСТАНОЇ ЛІТЕРАТУРИ}

1. "Про Стратегічний оборонний бюлетень України" - Режим доступу: http://www.president. gov.ua/news/prezident-zatverdiv-strategichnijoboronnij-byuleten-ukrayin-37309.

2. В. М. Барыкин. Проблемы развития систем управления на современном этапе / В. М. Барыкин // Военная мысль. - 1996. - № 4. C. 29-32.
3. Морозов А. О., Кузьменко Г. Э., Яровий А. Д. Основні проблеми інформатизації Збройних Сил України на сучасному етапі // Наука і оборона. 2004. - № 3. - C. 16-22.

4. Морозов А. О. Управління розробкою Єдиної АСУ збройних сил. // А. О. Морозов, В. А. Косс // Наука і оборона. - 2006. - № 2. - С. 30-34.

5. Шевченко В. Л. Особливості впровадження та використання ERP-систем як сучасного інструменту управління ресурсами у військовій

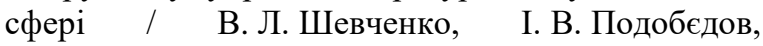
В. А. Козачок // Сучасні інформаційні технології у сфері безпеки та оборони. - 2009. - № 1(4). C. 25-29.

6. Андерсон Д. SAP за 24 часа: підруч. // Андерсон Д., Ларока А. - Днепропетровск: Баланс Бизнес Букс, 2007. - 400 с.

7. Информационная технология. Комплекс стандартов на автоматизированные системы. Автоматизированные системы. Стадии создания ГОСТ 34.601-90. Режим доступу: http://vsegost.com/Catalog/10/10698.shtml

Стаття надійшла до редакційної колегії 20.03.2019

Галаган В. И., канд. воен. наук, доцент;

Полишко С. В., канд. техн. наук, ст. науч. сотрудник;

Бондарчук С. В.

Центр военно-стратегических исследований Национального университета обороны Украины имени Ивана Черняховского, Киев

Предложения по совершенствованию процесса внедрения информационных систем иностранного производства в деятельность Вооруженных Сил Украины

Резюме. В статье проведен сравнительный анализ подходов к разработке и внедрению информационных систем иностранного производства с требованиями нормативных документов Украины и на его основе разработаны рекомендации по решению проблемных вопросов понимания этапов (фаз, процессов) разработки и внедрения информационных систем иностранного производства в деятельность военных организаций (структур ) Вооруженных Сил Украины.

Ключевые слова: внедрение информационных систем; этапы разработки и внедрения; совершенствования процесса внедрения.

V. Galagan, PhD (Military), assistant professor;

S. Polishko, PhD (Technical), senior researcher;

S. Bondarchuk

Center for Military and Strategic Studies National Defence University of Ukraine named after Ivan Chernyhovskyi, Kyiv

Proposals on the improvement of the process of introduction of information systems of foreign production into the activities of the Armed Forces of Ukraine

Resume. In the article a comparative analysis of approaches to the development and implementation of information systems of foreign production with the requirements of normative documents of Ukraine and on its basis developed recommendations for solving problematic questions of understanding the stages (phases, processes) of the development and implementation of foreign information systems in the activities of military organizations (structures) The Armed Forces of Ukraine.

Keywords: introduction of information systems; stages of development and implementation; improvement of the implementation process. 